\title{
ANALYZING VARIOUS MODELS OF INTERNAL MARKETING STRATEGIES
}

\author{
Bundit Pungnirund
}

\section{Paweena Sribunreng}

Suan Sunandha Rajabhat University, Bangkok, Thailand

Internal marketing is considered as an academic, scientific, and commercial knowledge of improving the level of customer satisfaction. This branch of marketing science is largely influenced by quality management and service marketing, which emphasizes the importance and necessity of creating quality throughout the service delivery process. This field of marketing science discusses the relationship between the customers and internal suppliers of the organization (employees) in creating value for foreign customers, this can be appeared as a chain of value and a tool for developing the quality of products and services and interorganizational and outsourced interactions within the organization (Ling, 2000). Today, domestic marketing is known as a strategy to improve the performance of the organization. Related studies in this realm show that internal marketing activities will improve the organization's competitiveness and enhance competency through empowering and motivating employees. Despite the expansion of this concept in the marketing literature, practically little use has been made of it. The internal marketing argument is that the first customers of each organization are its employees. By examining the factors affecting internal marketing, it is clear that there are many factors that affect domestic marketing. Over the past 20 years, many models have evolved from domestic marketing. In this article 12 models of them will be covered in detail. Then, in the end, they will be criticized, and these models will be examined.

Keywords: internal marketing, staff, model

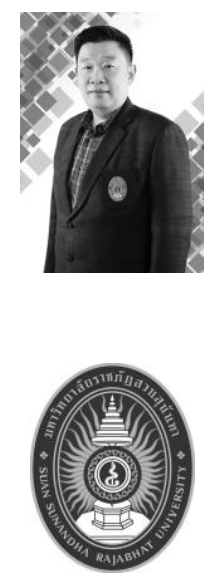

\section{Bundit Pungnirund}

$\mathrm{PhD}$ (Innovative Management), assistant profesor, Dean of College of Innovation and Management Suan Sunandha Rajabhat University, Bangkok Thailand

Research fields: innovative management, efficiency of corporative logistic and value chains, government support of SMEs, regionalization and integration processes in ASEAN, new products development, marketing strategies for modern companies

Published more than 35 research papers in international journals

E-mail: Bunditpung@ @otmail.com, Bundit.pu@ssru.ac.th

Paweena Sribunreng

Researcher in Suan Sunandha Rajabhat University, Bangkok, Thailand

Research interests: innovative management, innovative economy, creativeness and business

E-mail: paweena.sr@ssru.ac.th 


\section{ANALYZING VARIOUS MODELS OF INTERNAL MARKETING}

\section{Introduction}

Organizing and/or being organized is the core feature of our times. In the course of our life we are permanently involved in various organizations, and even when we die, we still become subjects to organization. Every organization consists of organs which are vitally important for organization. These "organs" include structure, technology, objectives, capital resources, human resources and so on. Although the existence of all these elements is important for the organization overall, it is the human resources that are the most important part of business organizations. Most scientists treat human management as the core and the engine of organization, thus, special attention must be paid to it at all times. Staff of a business organization can be also seen as internal customers, thus, some sort of domestic/internal marketing must be applied to it. The more business invests in own employees, the more beneficial results will it get in terms of own organizational performance.

Businesses that pay sufficient attention to own employees usually have more customeroriented employees. Additionally, stronger job satisfaction and organizational commitment are observed. Internal marketing as a separate area in marketing was first formulated by Strauss \& Corbin (1998) as a way to settle various issues related to human resources in business. One of central ideas in the initial concept was that all personnel of the same company will accept the behavior, attitude and marketing orientation when dealing with external customers.

As it is obvious from the above, the target group in internal marketing is company's human resources (Camison et al., 2014). As Gounaris et al. (2004) went with this idea slightly further: since employees are sort of internal customers, then business is partially an internal product, thus, internal marketing is nothing but application of external marketing inside the organization. According to Growther et al. (2000), internal marketing, first and foremost, means well-tuned working relationships between employees and employees with management. Internal marketing can be also seen as company's effort to meet the needs of staff thus making the latter more efficient overall (Basirat et al., 2015) or more effective in terms of management of the value-service chain and communications (Awwad et al., 2011).

To sum up, the key objective of internal marketing is to make sure that all activities and programs are well accepted inside organization, thus can be smoothly implemented so that to become successful on the side of external customers already. There is still a place for minor confusion here as sometimes internal marketing can be seen as fully equal to human resource management. Indeed, these two concepts share several important features,still they are not the same. HR management is mostly about trainings, employment and career planning, while internal marketing provides more like an overall guidance on how to use these HR instruments for methods to improve business performance overall (Gordon, 2005).

Internal marketing stems from the idea that all employees together form the internal market of an organization. Nowadays, internal marketing is often seen as the strategic level in implementation the internal enterprise program. Numerous studies in this field state that internal marketing tends to improve the overall competitiveness of businesses through empowerment and motivation and competencies' promotion. Such a vision is especially relevant for service organizations, as for this type of businesses staff always plays the key role in attracting new clients and retaining loyal ones. 
Thus, the objective of the current study has been the analysis of the selected internal marketing models offered by the researchers from several rather different countries. In the final part of our research we intend to answer the question: what kind of variations can be in this model and how can they be resolved?

\section{Internal Marketing Conceptualization and Implementation}

Literature database on internal marketing (IM) is expanding all the time and quite intensively (Barzoki et al., 2013). In our opinion, Rafigh and Ahmed have presented one of the most comprehensive definitions for internal marketing: planned efforts based on marketing approaches to overcome organizational resilience to change along with other balancing, motivating and coordinating tasks so that to integrate employees for more effective implementation of corporate tasks and strategies, with the final aim being to reach customer satisfaction thanks to more customer-driven employees (Ahmed \& Rafigh, 2003).

Tsai (2014) offered an original framework for the internal marketing concept. In his framework there are two dimensions which are: the dimension for interaction (exchange of ideas and relations), and the dimension of the organizational goals (both short-term and longterm, their focus can be also inner or external). This framework also covers four integrated marketing mixes, strategic internal marketing, collective internal marketing, and internal relational management. In such a context, (Cooper \& Cronin, 2000) sees internal marketing as a set of efforts made by an organization to educate and encourage own staff and to manage human resources so that they provide better services. Carter understood internal marketing as an integral part of market orientation, which includes application of marketing techniques inside the organization itself so that to communicate company values in the clearest way.

Nowadays, internal marketing is sometimes seen as a strategy of market orientation. At the same time, Sasser et al. (1989) saw and presented market orientation is a concept of foreign marketing, which means, inter alia, detecting and satisfying customer needs more effectively as compared to the nearest competitors. Ahmed and Rafigh (2003) studied the selected range of service organizations in the UK and came up with the following internal marketing indicators: internal communications, information sharing, staff trainings, empowerment, working in teams and other group activities, direct participation of staff in determining organizational vision.

Today, when the very concept of internal marketing is gaining popularity, the importance of understanding internal customers of organizations (or, in other words, their employees) has become one of the key success factors for businesses of all sizes.

In several studies on this topic, internal marketing has been presented as implementation of an organizational strategies and the term "internal marketing mix" has been used in such a context.

Abzari and colleagues (2009) evaluated the effects from internal marketing on market orientation and organizational performance. These authors used questionnaires on the sample of 100 managers and supervisors working in the hotels of the Isfahan city. Then, they developed a model to demonstrate the effect from internal marketing on organizational performance, this effect was also tested using Laserl. Once the results of the survey were analyzed, it was determined that internal marketing, through market orientation, affects organizational performance. The fitting indices (GFI $=0.98$, AGFI $=0.97)$ of the model confirmed its suitability. 


\section{ANALYZING VARIOUS MODELS OF INTERNAL MARKETING}

\section{Discussion and Concluding Remarks}

Since today the proposition grows and expands across all business sectors without any exception, all business organizations feel the need to improve the quality of their products and services. This automatically means that organizations have to boost their organizational capabilities so that to provide high-quality products and services. Employees as internal customers of companies are playing the leading role in this context. Boosting their development, strengthening their motivation, promoting their ability of value creation would mean continuous improvement of work quality. Another important component of higher quality is direct participation of staff at both strategic and operational levels of doing business as this would help management to guarantee higher level of quality for all products and services. And this, in turn, would mean much stronger satisfaction among external customers.

To achieve organizational goals through internal marketing mechanisms, organizations need to concentrate on improving the level of staff quality through via occupational enrichment, training, extra benefits and rewards, guarantees of job security, easier communication in the offices.

Considering all of the above, the importance of internal marketing for business revenues and business success overall is very much obvious. As part of our concluding remarks, we can recommended organizations change their style of thinking about own employees: attracting new employees seems to be much more difficult and not that beneficial as opposed to having loyal long-term employees. The age when top management was looking down on employees with some sort of suspicion is most definitely over.

Building continuous, long-term relations with staff can rather quickly put the company in line with needs and expectations of the customers and thus can also help with planning future marketing strategies. For this very reason, recognizing the value of internal marketing and designing marketing strategies accordingly becomes one of the vitally important requirements that all top managers should pay attention to. Above, we have reviewed in detail 12 internal marketing models that ultimately lead us to constructing a comprehensive internal marketing model with the most appropriate variables. To some extent, this model can be seen as a road map.

However, some of these models can be actually seen as alternatives to each other since many of the variables put forward by the researchers have a lot of similarities. Therefore, we conclude that the starting point should be always understanding and evaluating the specific background. Our comprehensive model does not only cover all the cases described above, in the context of specific organizations and their current needs, but it also shows that in the near future already business success will belong only to the organizations that are constantly learning. This model considers internal marketing as a process which organizations must integrate into all other processes within them and then also take efforts to protect internal marketing from neglecting.

Each step in this process, however, should be understood as complementary, even though in many cases one step is actually the preparation for the next one: recruitment of employees - their on boarding - provision of organizational strategy - formation and cultivation of organizational culture and organizational climate - education and empowerment of all staff until retirement and finally, the actual retirement. Only provided 
this continuity is carefully kept and monitored, the employees have strong enough incentive to follow the internal marketing strategy and act accordingly.

\section{References:}

Abzari, M., Ranjbarian, B., Fathi, S. \& Ghorbani, H. (2009). Effect of internal marketing on marketorientation and organizational performance in Hoteling industry. Journal of Management vision. (31): 25-42.

Abzari, M., Ranjbarian, B., Fathi, S. \& Ghorbani, H. (2009). The Effect of Internal Marketing on Market Orientation and Organizational Performance in Hotel Industry. Management Perspectives, (31), 25-42.

Ahmed, P., Rafiq, M., \& Saad, N. (2003). Internal Marketing and the Mediating Role of Organizational Competencies. European Journal of Marketing, 37(9), 1221-1241.

Awwad, M, S., \& Agti, D. A. M. (2011). The Impact of Internal Marketing on Commercial Banks Market Orientation. International Journal of Bank Marketing, 4(29), 308-332.

Barzoki, A. S. \& Ghujali, T. (2013). Study the Relationship of Internal Marketing with Job Satisfaction, Organizational Commitment and Organizational Citizenship Behavior. International Journal of Academic Research in Business \& Social Sciences, 3(3), 33-49.

Basirat, M., Imani, S., Zaranezhad, M., \& Dehghan Najmabadi, A. (2015). Evaluate effects of internal marketing on organizational commitment with emphasis on the role of mediator is entrepreneurial orientation (The case of headquarters Agha-Jari oil and gas operation company). Productivity Management, 8(32), 147-169.

Camisón, C., \& Villar-López, A. (2014). Organizational innovation as an enabler of technological innovation capabilities and firm performance. Journal of Business Research, 67(1), 2891-2902.

Cooper, J. \& Cronin, J. (2000). Internal Marketing: Competitive Strategy for the Long-Term Care Industry. Journal of Business Research, 8(6), 177-181.

Gordon Z. (2005). The effect of distributed leadership on student achievement. Doctoral Dissertation, Central Connecticut State University, 2005.

Gounaris, S. P., Avlonitis, G. J., \& Papastathopoulou, P. (2004). Managing a firm's behavior through market orientation development: some empirical finding. European Journal of Marketing, 38(11/12), 1481- 1508 .

Sasser, W. E., \& Arbeit, S. F. (1989). Selling Jobs in the Service Sector. Business Horizons, 2, 2-61.

Strauss, A. \& Corbin, J. (1998). Grounded theory methodology. In: N. K. Denzin, \& Y. S. Lincoln (eds.). Strategies of qualitative inquiry (158-183). Thousands Oaks, CA: Sage Publications.

Tsai, Y. (2014). Learning organizations, internal marketing, and organizational commitment in hospitals. BMC health services research, 14(152), 1-8.

Paper submitted

Paper accepted for publishing

Paper published online
07 March 2019

26 April 2019

25 June 2019 